\title{
PENENTUAN PUSAT PELAYANAN PERKOTAAN DI KOTA TANJUNGPINANG
}

\author{
Mita Apriana, Iwan Rudiarto \\ Program Studi Perencanaan Wilayah dan Kota, Universitas Diponegoro \\ Jalan Prof. Soedharto SH, Tembalang, Semarang, Jawa Tengah 50239 \\ Email corresponding: mt.apriana@gmail.com
}

\begin{tabular}{|c|c|c|}
\hline Dikirimkan: & Diterima: & Diterbitkan: \\
24-02-2020 & $20-06-2020$ & $26-07-2020$ \\
\hline
\end{tabular}

\begin{abstract}
As a developing region, the problem of inequality development is a challenge for Tanjungpinang City so that the determination of centre place is the most important to do. The objective of this study is to identify areas in Tanjungpinang that have the potential as a central place. Quantitative approach was applied with central place, scalogram, and spatial interaction analysis as the assessment tools. The results indicate that Tanjungpinang Timur district has the potential as a central place in Tanjungpinang City which has 23 types of service facilities and totalling 550 units. It influenced on the strength of spatial interaction among districts in Tanjungpinang City. The highest spatial interaction value is Tanjungpinang Timur district of 236,428,545 and the lowest is Tanjungpinang Kota District of 21,002,925. These results can be a consideration for the local governments to determining the direction of regional development. By optimizing central places, the issue of development inequality in Tanjungpinang City can be avoided.
\end{abstract}

Keywords: scalogram; christaller; Marshall Index; central place; Tanjungpinang

\begin{abstract}
Abstrak
Sebagai wilayah yang sedang berkembang, permasalahan kesenjangan dan ketidakmerataan pembangunan menjadi sebuah tantangan bagi Kota Tanjungpinang sehingga penentuan pusat pelayanan perkotaan menjadi hal yang penting untuk dilakukan. Penelitian ini bertujuan untuk mengidentifikasi wilayah di Kota Tanjungpinang yang berpotensi sebagai pusat pelayanan perkotaan. Metode yang digunakan pada penelitian ini adalah pendekatan kuantitatif dengan analisis orde perkotaan berdasarkan teori tempat pusat/central place, yaitu dengan menggunakan analisis skalogram dan analisis interaksi keruangan. Hasil analisis menyatakan pusat pelayanan utama di Kota Tanjungpinang berada di Kecamatan Tanjungpinang Timur, memiliki 23 jenis fasilitas pelayanan sebanyak 550 unit, dengan nilai interaksi keruangan tertinggi sebesar $236,428,545$, sedangkan yang memiliki nilai interaksi terendah adalah Kecamatan Tanjungpinang Kota sebesar 21,002,925. Hasil penelitian dapat menjadi bahan pertimbangan pemerintah daerah untuk mengoptimalkan pusat-pusat pelayanan dalam menentukan arah pembangunan dan pengembangan wilayah, agar isu kesenjangan dan ketidakmerataan pembangunan di Kota Tanjungpinang dapat dihindari.
\end{abstract}

Kata Kunci: skalogram, indeks sentralitas Marshall, pusat pelayanan, Tanjungpinang 


\section{PENDAHULUAN}

Kesenjangan dan pemerataan pembangunan merupakan isu krusial nasional dan daerah. Suryana \& Hafil (2019) dalam situs online republika.co.id pada Selasa, 5 November 2019 memberitakan penurunan kesenjangan antar wilayah menjadi salah satu isu strategis dan menjadi prioritas pembangunan nasional. Permasalahan yang terjadi, fenomena kesenjangan antarwilayah mengarah kepada kemiskinan dan ketertinggalan (Hidayat, 2018). Kesenjangan merupakan fenomena perbedaan antar wilayah dikarenakan ketidakmerataan pembangunan antarwilayah dan salah satu cara yang dapat dilakukan untuk mengatasi kesenjangan adalah dengan mengoptimalkan pusat-pusat pelayanan (Muliana, Astuti, \& Fadli, 2018).

Pusat pelayanan atau lebih dikenal dengan central place menurut Walter Christaller (18931969) merupakan kota-kota yang menyajikan barang dan jasa bagi masyarakat di wilayah sekelilingnya dengan membentuk suatu hirarki berdasarkan jangkauan (range) dan ambang batas (treshold) penduduk (Muliana et al., 2018). Suatu pusat aktivitas yang senantiasa melayani berbagai kebutuhan penduduk harus terletak pada suatu lokasi yang sentral yaitu suatu tempat atau wilayah yang memungkinkan partisipasi manusia dalam jumlah maksimum, baik mereka yang teribat dalam aktivitas pelayanan maupun yang menjadi konsumen dari barang dan jasa tersebut (Utoyo, 2007). Pusat wilayah berfungsi sebagai: (1) tempat terkonsentrasinya penduduk (permukiman); (2) pusat pelayanan terhadap daerah hinterland; (3) pasar bagi komoditas-komoditas pertanian maupun industri; dan (4) lokasi pemusatan industri manufaktur (Rustiadi, 2009). Asumsi yang digunakan pada teori ini antara lain: (a) Karena para konsumen yang menanggung ongkos angkutan, maka jarak ke tempat pusat yang dinyatakan dalam biaya dan waktu, amat penting; (b) Karena konsumen yang memikul ongkos angkutan, maka jangkauan (range) suatu barang ditentukan oleh jarak yang dinyatakan dalam biaya dan waktu (Januarman, Ahyuni, \& Purwaningsih, 2018).

Kota Tanjungpinang merupakan ibukota Provinsi Kepulauan dengan koordinat $0{ }^{\circ} 5^{\prime} \mathrm{LU}$ dan 104'27' BT dengan memiliki 4 wilayah kecamatan. Wilayahnya berbatasan dengan Kabupaten Bintan dan berada dalam satu pulau bernama Pulau Bintan. Menurut ukurannya, Kota Tanjungpinang termasuk kota sedang yang berpenduduk 209,280 jiwa (BPS, 2019). Melalui Undang-Undang Nomor 25 Tahun 2002 tentang Pembentukan Provinsi Kepulauan
Riau, Kota Tanjungpinang ditetapkan sebagai daerah ibukota provinsi. lbukota Tanjungpinang terletak di Kecamatan Tanjungpinang Kota bernama Senggarang, sedangkan pusat pemerintahan Provinsi berada di Pulau Dompak, Kecamatan Bukit Bestari. Sebagai daerah yang sedang berkembang, permasalahan kesenjangan dan pemerataan pembangunan menjadi sebuah tantangan bagi Kota Tanjungpinang, sehingga penentuan pusat pelayanan menjadi hal yang penting untuk dilakukan. Pemerintah daerah juga mengamanatkan agar meningkatan pusat pelayanan yang fungsional, berhierarki, dan terintegrasi, karena kunci bagi pertumbuhan sekaligus pemerataan di suatu wilayah adalah melalui penciptaan hubungan (keterkitan) yang saling menguntungkan antar pusat-pusat pertumbuhan juga dengan wilayah pengaruhnya (Firmansyah, Hariyanto, \& Indrayati, 2016).

Analisis skalogram digunakan untuk mengidentifikasi peranan suatu kecamatan berdasarkan pada kemampuan masing-masing kecamatan dalam memberikan pelayanan kepada masyarakat, dengan berisi data semua nama pusat wilayah, jumlah penduduk, jumlah jenis dan sarana pelayanan dicatat dalam sebuah format matriks (Rustiadi, 2009; Rahayu \& Santoso, 2014). Analisis skalogram juga memberikan gambaran adanya pengelompokkan permukiman sebagai pusat pelayanan dengan mendasarkan pada kelengkapan fungsi pelayanannya (Utari, 2015). Dari uraian di atas, rumusan masalah penelitian adalah dimanakah wilayah Kota Tanjungpinang yang berpotensi untuk menjadi pusat pelayanan?; Adakah indikasi kesenjangan pembangunan di Kota Tanjungpinang?, sehingga penelitian ini bertujuan untuk mengidentifikasi wilayah di Kota Tanjungpinang yang berpotensi menjadi pusat pelayanan.

Penelitian terdahulu (Jacob \& Hasan, 2016; Muliana et al., 2018) menggunakan analisis skalogram untuk menentukan pusat-pusat pelayanan. Beberapa penelitian lain (Gulo, 2015; Utari, 2015) menambahkan model gravitasi untuk melihat interaksi antar pusat pelayanan dan Hailuddin, Fadliyanti, \& Wijimulawiani, (2018) secara khusus menggunakan faktor perhubungan, ekonomi, kesehatan, dan pendidikan dan mengkombinasikan dengan model gravitasi dan indeks williamson untuk menganalsis pusat pertumbuhan ekonomi dan kontribusinya pada pengembangan daerah pendukung. Dari beberapa sumber tersebut di atas, penelitian ini 
menggunakan metode analisis Christaller, analisis skalogram dan menambahkan analisis keruangan dengan model gravitasi untuk menganalisis kekuatan interaksi antar pusat pelayanan. Analisis keruangan bermanfaat dalam bidang analisis perencanaan wilayah dengan anggapan dasar bahwa faktor aglomerasi penduduk, pemusatan kegiatan atau potensi sumber daya alam yang dimiliki, mempunyai daya tarik yang dapat dianalogikan sebagai daya tarik menarik antara 2(dua) kutub magnet (Octaria \& Hidayat, 2015).

\section{Interaksi Keruangan dan Pembangunan Wilayah}

Interaksi keruangan merupakan suatu hubungan timbal-balik yag saling berpengaruh antar dua wilayah atau yang lebih dapat menimbulkan gelaja, kenampaka, atau permasalahan baru (Utoyo, 2007). Kuatlemahnya sangat dipengaruhi oleh tiga faktor utama, yaitu wilayah-wilayah yang saling melengkapi (regional complementary), adanya kesempatan untuk berintervensi (interventing oppotunity), serta adanya kemudahan transfer atau pemindahan dalam ruang (spatial transfer ability) (Kharisma \& Triwardani, 2018). Aplikasi interaksi keruangan dapat digunakan dalam perencanaan pembangunan, seperti penempatan lokasi pusat pelayanan dan pembangunan prasarana trasportasi (Habib, 2016). Interaksi keruangan mengacu pada teori gravitasi Newton (1687) bahwa dua buah benda yang memiliki massa tertentu akan memiliki gaya tarik menarik antara keduanya yang dikenal sebagai gaya gravitasi, kemudian diterapkan oleh W.J Reilly (1929) mengukur kekuatan interaksi keruangan antara dua wilayah atau lebih (Hermawati \& Sari, 2018). Reilly (1929) dalam Latifah, et. al, (2018) berpendapat bahwa kekuatan interaksi antar 2 wilayah yang berbeda dapat diukur dengan memperhatikan faktor jumlah penduduk dan jarak kedua wilayah tersebut.

\section{METODOLOGI PENELITIAN Lokasi Penelitian}

Lokasi penelitian adalah Kota Tanjungpinang, Provinsi Kepulauan Riau (Gambar 1) dengan batas-batas wilayah administrasi Kota Tanjungpinang adalah sebelah utara, timur dan selatan berbatasan dengan Kabupaten Bintan dan sebelah barat berbatasan dengan Kota Batam. Secara administratif, Kota Tanjungpinang terdiri dari 4 (empat) kecamatan yaitu Kecamatan Tanjungpinang Barat, Kecamatan Tanjungpinang Timur, Kecamatan Tanjungpinang Kota dan Kecamatan Bukit Bestari, terdiri dari 18 kelurahan, 168 RW dan 680 RT. Luas wilayahnya mencapai $258.82 \mathrm{~km}^{2}$ yang terdiri dari $150.86 \mathrm{~km}^{2}$ daratan dan $107.96 \mathrm{~km}^{2}$ lautan dengan keadaan geologis sebagian berbukit-bukit dan lembah yang landai sampai ke tepi laut (Tabel 1) (BPS, 2019).

\section{Kebutuhan Data}

Penelitian ini menggunakan data sekunder Tahun 2018, bersumber dari publikasi Badan Pusat Statistik Kota Tanjungpinang. Data yang digunakan berupa data jumlah penduduk, data fasilitas pendidikan, peribadatan, perdagangan, dan kesehatan. Subjek pada penelitian ini adalah 4 kecamatan di Kota Tanjungpinang, yaitu Kecamatan Tanjungpinang Barat, Kecamatan Tanjungpinang Timur, Kecamatan Tanjungpinang Kota dan Kecamatan Bukit Bestari.

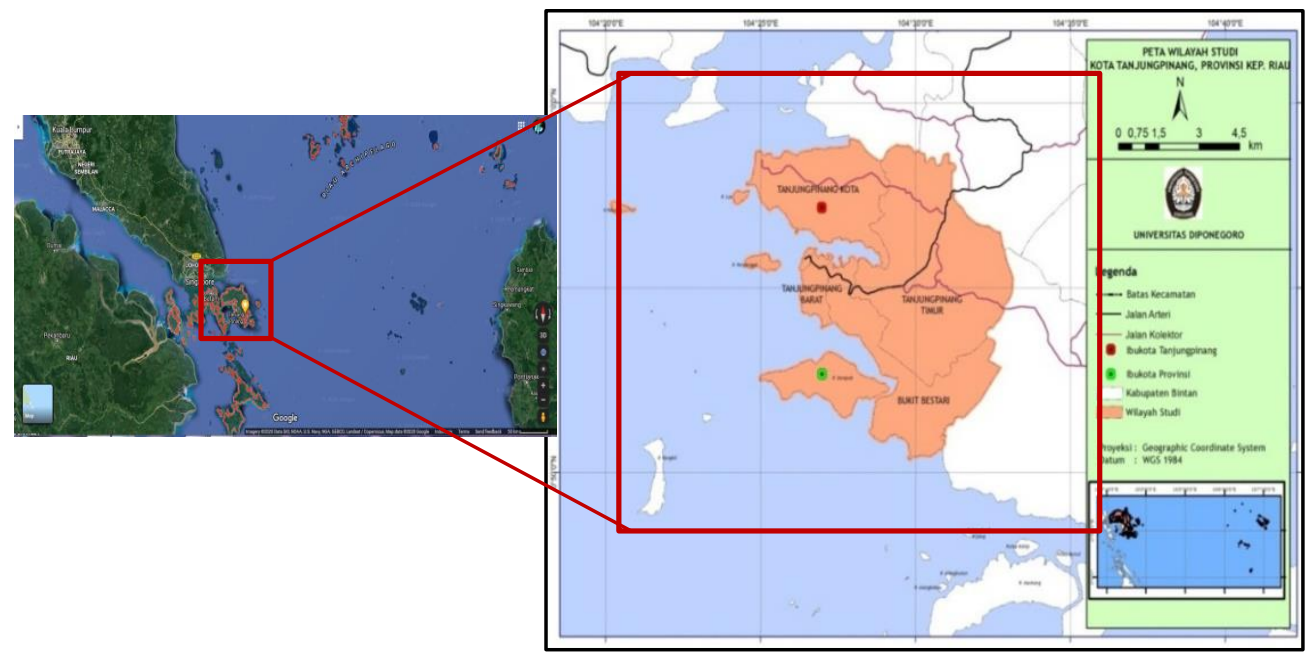

Gambar 1. Peta Wilayah Studi 
Tabel 1. Profil Wilayah Administratif Kota Tanjungpinang

\begin{tabular}{clccc}
\hline \multirow{2}{*}{ No } & Kecamatan & $\begin{array}{c}\text { Jumlah Penduduk } \\
\text { (jiwa) }\end{array}$ & $\begin{array}{c}\text { Luas } \\
\left(\mathrm{m}^{2}\right)\end{array}$ & $\begin{array}{c}\text { Kepadatan } \\
\left(\text { jiwa } / \mathrm{km}^{2}\right)\end{array}$ \\
\hline 1 & Tanjungpinang Timur & 83,670 & 60.04 & 1,394 \\
2 & Bukit Bestari & 61,005 & 46.51 & 1,312 \\
3 & Tanjungpinang Barat & 46,607 & 4.62 & 10,088 \\
4 & Tanjungpinang Kota & 17,998 & 39.69 & 453 \\
\hline & Jumlah & $\mathbf{2 0 9 , 2 8 0}$ & $\mathbf{1 5 0 . 8 6}$ \\
\hline
\end{tabular}

\section{Metode Analisis}

Metode penelitian menggunakan pendekatan kuantitatif dengan analisis data menggunakan teori Central Place Christaller, analisis skalogram dan analisis interaksi keruangan sebagaimana yang dilakukan (Muliana et al., 2018; Utari, 2015; \& Gulo, 2015) dengan tahapan sebagai berikut:

1) Menghitung Orde Perkotaan Berdasarkan Christaller

Menurut metode Christaller, perbandingan jumlah penduduk antara kota orde lebih tinggi dengan kota orde setingkat lebih rendah setidaknya tiga kali lipat (Valetin \& Pangi, 2017). Dengan kata lain, jumlah penduduk pada orde yang lebih rendah adalah sepertiga dari jumlah penduduk orde yang lebih tinggi. Misalnya pada penelitian ini, Kecamatan
Tanjungpinang Timur memiliki jumlah penduduk lebih tinggi yaitu 83,670 jiwa sehingga berorde 1, maka perhitungan orde di bawahnya adalah $1 / 3$ dari $83,670=27,890$, demikian seterusnya.

2) Menghitung Skalogram

Penelitian ini menilai fasilitas yang memberikan fungsi baik pelayanan sosial maupun pelayanan ekonomi, jenis fasilitas yang dinilai anatar lain: fasilitas kesehatan, peribadatan, perdagangan dan pendidikan (Tabel 2) sebagaimana Utari (2015) mendeskripsikan fasilitas yang digunakan dalam perhitungan skalogram adalah fasilitas yang mencirikan fungsi pelayanan sosial dan ekonomi dengan kriteria obyek tunggal dan terukur serta sedapatnya memiliki karakteristik hirarkis atau berjengjang.

Tabel 2. Daftar Jenis Fasilitas Pelayanan di Kota Tanjungpinang

\begin{tabular}{cl}
\hline No. & Jenis Fasilitas \\
\hline 1 & TK \\
2 & SD \\
3 & SMP \\
4 & SMA \\
5 & Posyandu \\
6 & Balai Kesehatan \\
7 & Mesjid \\
8 & Musholla \\
9 & Gereja \\
10 & Wihara \\
11 & Industri Besar \\
12 & UMKM \\
\hline
\end{tabular}

Pada perhitungan skalorgam, asumsi yang digunakan adalah wilayah yang memiliki fasilitas terlengkap merupakan orde tertinggi dan ditetapkan sebagai pusat pelayanan. Perhitungan dilakukan dengan teknik present dan absent, dimana wilayah yang memiliki fasilitas diberi nilai 1 sedangkan wilayah yang yang tidak memiliki fasilitas diberi nilai 0 . Angka-angka tersebut kemudian dijumlahkan secara vertikal dan horizontal. Wilayah yang memiliki fasilitas paling lengkap diposisikan pada baris paling atas dan fasilitas-fasilitas yang

\begin{tabular}{cl}
\hline No. & Jenis Fasilitas \\
\hline 13 & Hotel \\
14 & Bank \\
15 & Universitas \\
16 & Puskesmas \\
17 & Pelabuhan \\
18 & Rumah Sakit \\
19 & Polindes \\
20 & Pasar \\
21 & SMK \\
22 & Rumah Bersalin \\
23 & Klenteng \\
24 & Bandara \\
\hline \multicolumn{2}{c}{ Sumber: BPS Kota Tanjungpinang, 2019 }
\end{tabular}

dimiliki wilayah tersebut (bernilai 1) diposisikan pada baris paling kiri sehingga membentuk hirarki anak tangga. Perhitungan dilanjutkan dengan menguji kelayakan skalogram menggunakan persamaan (1)

COR $=\frac{1-\mathrm{a}}{\mathrm{b} \times \mathrm{c}} \cdots \cdots \cdots \cdots . . . .(1)$

Dimana: COR (Coeffisien of Reproducibility) adalah koefisien kelayakan; a adalah jumlah kesalahan; b adalah jumlah kecamatan yang dianalisis; dan $c$ adalah jumlah jenis fasilitas yang digunakan dalam perhitungan. Ketentuan 
nilai atau tingkat kelayakan nilai pada analisis ini Hirarki Nilai COR yang ideal antara 0,9 - 1 .

3) Menghitung Indeks Sentralitas Marshall

Analisis ini memperhitungkan banyaknya unit fasilitas pelayanan, sehingga asumsi yang digunakan adalah wilayah yang memiliki unit fasilitas pelayanan terbanyak merupakan orde tertinggi dan ditetapkan sebagai pusat pelayanan. Perhitungan dilakukan dengan tahapan:

1. Menghitung bobot dari setiap unit fasilitas di masing-masing kecamatan dengan menggunakan persamaan 2:

$$
N=\frac{100}{c}
$$

Dimana: $\mathrm{N}$ adalah bobot dari setiap unit fasilitas; 100 adalah asumsi nilai sentralitas total; $c$ adalah jumlah seluruh unit fasilitas di Kota Tanjungpinang.

2. Menghitung Indeks Sentralitas (IS) setiap unit fasilitas di masing-masing kecamatan dengan menggunakan persamaan 3:

$$
\mathrm{IS}=\mathrm{N} \cdot \mathrm{y} \text {. }
$$

Dimana: is adalah Indeks Sentralitas; N adalah bobot dari setiap unit fasilitas, diperoleh dari persamaan (2) ; y adalah jumlah unit faslitas di masing-masing kecamatan yang secara rinci dijabarkan pada Tabel 6.

3. Menjumlahkan Indeks Sentralitas setiap kecamatan

4. Menghitung jumlah kelas (K) yang terbentuk menggunakan persamaan 4

$$
K=1+3.3 \log n
$$

Dimana: K adalah jumlah kelas; $\mathrm{n}$ adalah jumlah kecamatan yang dianalisis

5. Menghitung panjang interval kelas yang terbentuk menggunakan persamaan (5)

Tabel 3. Perhitungan Hirarki Kecamatan Berdasarkan Teori Christaler

\begin{tabular}{cc}
\hline Orde & Jumlah Penduduk \\
\hline I & 83,670 \\
II & 27,890 \\
III & 9,297 \\
\hline & Sumber: Hasil Penelitian, 2019
\end{tabular}

Hasil perhitungan orde tersebut mengklasifikasikan kecamatan di Kota Tanjungpinang seperti yang tersaji pada tabel 4. Kecamatan dengan orde tertinggi adalah kecamatan Tanjungpinang Timur karena memiliki jumlah penduduk terbanyak yakni 83,670 jiwa, sedangkan orde paling rendah adalah Kecamatan Tanjungpinang Kota karena memilki jumlah penduduk paling sedikit yakni 17,998 jiwa. Hasil ini memberi gambaran Kecamatan Tanjungpinang Timur merupakan pusat pelayanan yang memungkinkan partisipasi penduduk dalam jumlah maksimal.
Dimana: I adalah panjang interval kelas yang terbentuk; $\mathrm{T}$ adalah jumlah Indeks Sentralitas tertinggi; $\mathrm{t}$ adalah jumlh Indeks Sentralitas terendah, $\mathrm{K}$ adalah jumlah kelas yang terbentuk.

6. Menentukan hiraki/orde perkotaan yang terbentuk

4) Menghitung Interaksi Keruangan

Untuk memperkirakan daya tarik suatu lokasi pusat pertumbuhan wilayah dibandingkan lokasi lain atau wilayah belakangnya (hinterland), analisis interaksi keruangan dihitung menggunakan persamaan (6).

$$
\mathrm{NIaz}=\mathrm{k} \frac{\mathrm{Pa} \times \mathrm{Pz}}{(\mathrm{daz})^{2}}
$$

Dimana: Nlaz adalah besarnya interaksi wilayah a dengan wilayah z; Pa adalah jumlah penduduk di wilayah a (jiwa); Pz adalah jumlah penduduk di wilayah z (jiwa); daz adalah Jarak dari wilayah a dengan wilayah $\mathrm{z}(\mathrm{km}) ; \mathrm{k}=$ Angka konstanta empiris, bernilai 1.

\section{HASIL DAN PEMBAHASAN \\ Hirarki Kecamatan Berdasarkan Christaller}

Hirarki kota adalah hubungan antar kegiatan yang berpengaruh terhadap pola pemanfaatan ruang dalam skala wilayah yang dikenal dengan sistem kota atau orde kota berdasarkan skala pelayanan (Marasabessy, 2016). Dari hasil analisis berdasarkan Christaller didapatkan 3 orde/hiraki kecamatan yang disajikan pada tabel 3.
Sumber: Hasil Penelitian, 2019 
Tabel 4. Klasifikasi Orde Kecamatan

\begin{tabular}{|c|c|c|c|c|}
\hline No & Kecamatan & $\begin{array}{l}\text { Jumlah } \\
\text { (jiwa) }\end{array}$ & Penduduk & Orde \\
\hline 1 & Tanjungpinang Timur & 83,670 & & 1 \\
\hline 2 & Bukit Bestari & 61,005 & & II \\
\hline 3 & Tanjungpinang Barat & 46,607 & & II \\
\hline 4 & Tanjungpinang Kota & 17,998 & & III \\
\hline \multicolumn{2}{|c|}{ Jumlah } & 209,280 & & \\
\hline
\end{tabular}

Sumber: Hasil Penelitian, 2019

\section{Hirarki Kecamatan Berdasarkan Skalogram}

Dari hasil perhitugan skalogram berdasarkan kelengkapan fasilitas tiap-tiap kecamatan didapatkan 4 orde kecamatan yang dijabarkan pada Tabel 5.

Tabel 5. Hasil Perhitungan Analisis Skalogram Berdasarkan Kelengkapan Fasilitas di Kota Tanjungpinang

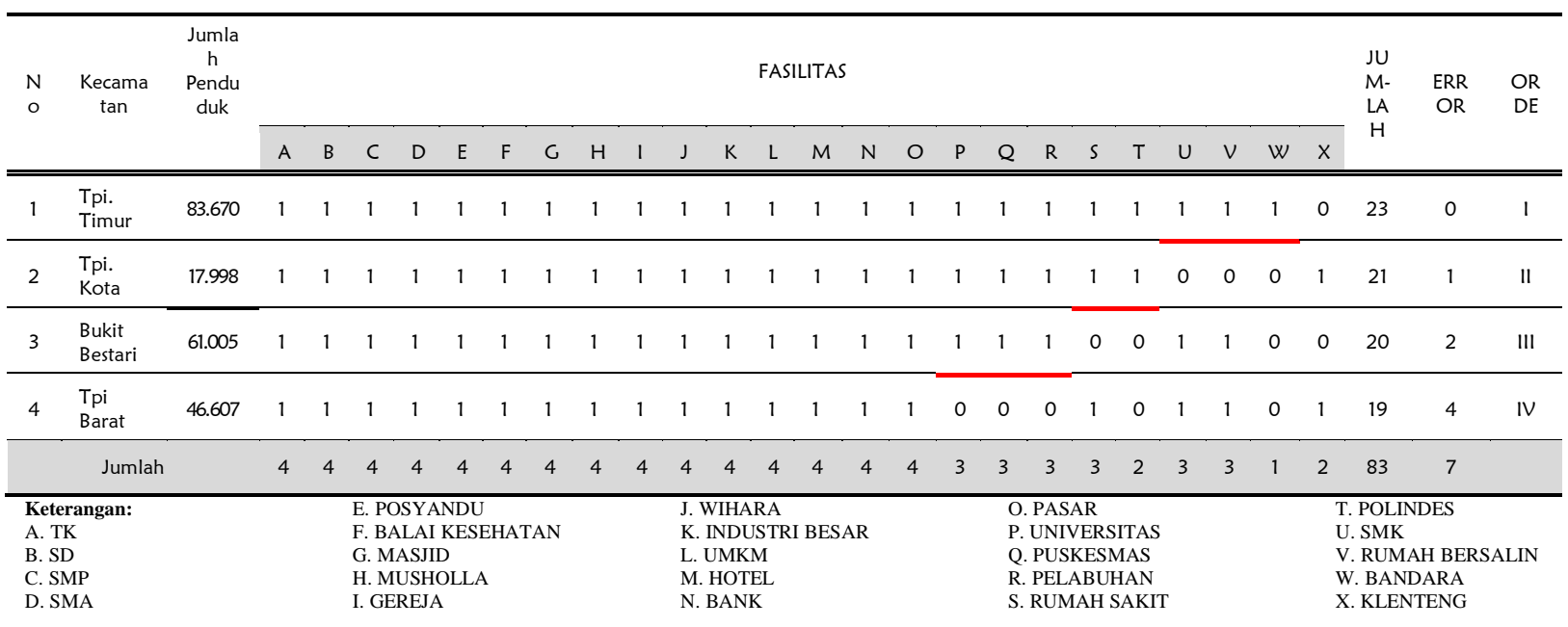

Sumber: Hasil Penelitian, 2019

Berdasarkan hasil perhitungan kelengkapan fasilitas masing-masing kecamatan pada tabel 5 , terdapat jumlah error $=7$ sehingga nilai COR $=0,927$ yang berarti metode ini layak untuk dilanjutkan pada penentuan orde kecamatan. Dari Tabel 5 di atas menggambarkan orde 1 merupakan kecamatan yang memiliki fasilitas paling lengkap yaitu Kecamatan Tanjungpinang Timur walaupun tidak memilki klenteng; orde II merupakan kecamatan yang memiliki fasilitas lengkap namun tidak selengkap orde I, yaitu Kecamatan Tanjungpinang Kota. Fasilitas yang tidak dimiliki adalah SMK, rumah bersalin dan bandara; orde III merupakan wilayah yang memiliki fasilitas, namun tidak selengkap orde I dan II yaitu Kecamatan Bukit Bestari dan fasilitas yang tidak dimiliki adalah rumah sakit, polindes, bandara dan klenteng; dan orde IV merupakan wilayah yang memiliki fasilitas kurang lengkap jika dibandingkan orde I, II, dan III yaitu Kecamatan Tanjungpinang Barat, fasilitas yang tidak dimiliki adalah universitas, puskesmas, pelabuhan, polindes, dan bandara. Secara spasial, hirarki wilayah tersebut dapat dilihat pada gambar 2 . 


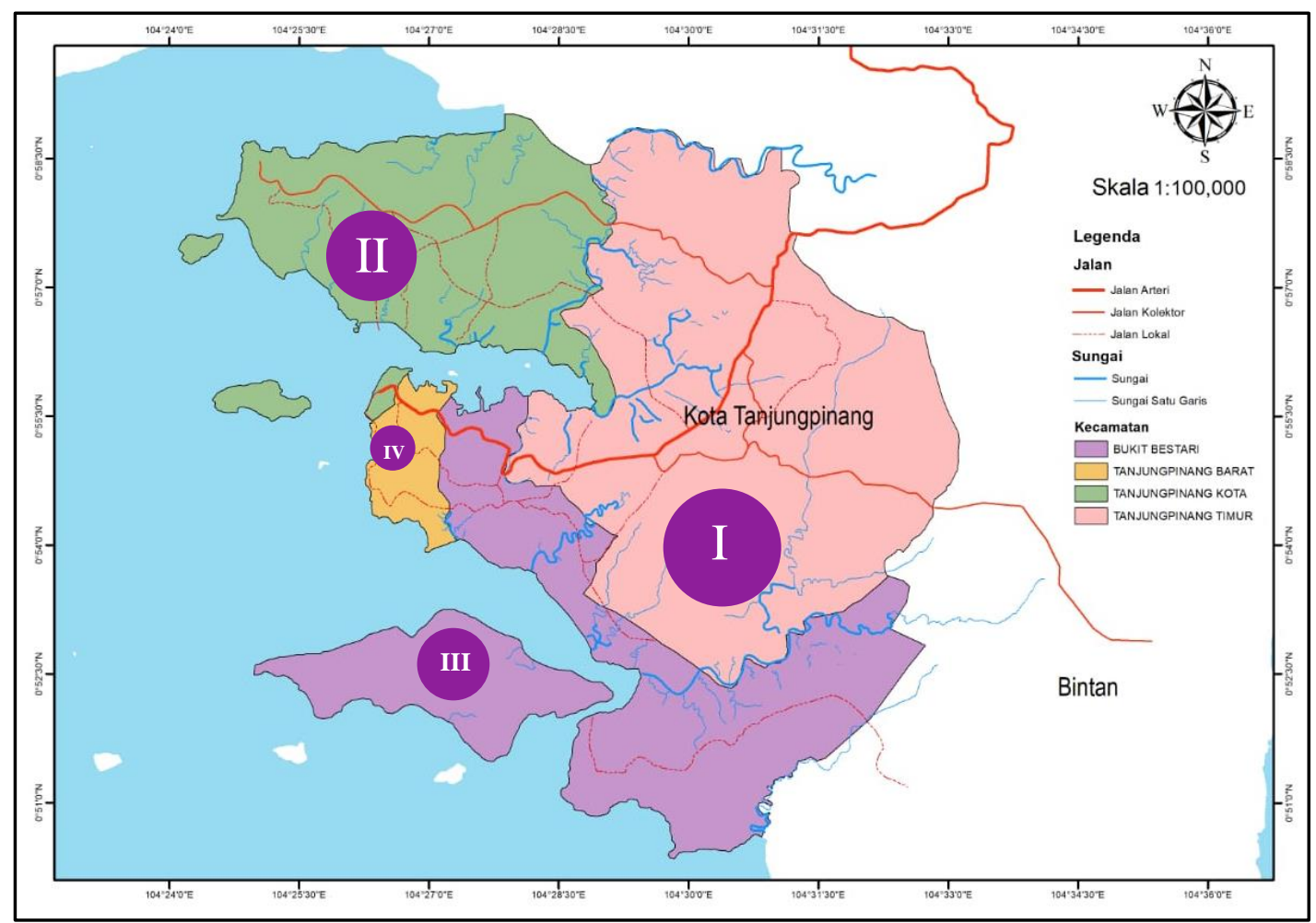

Gambar 2. Peta Hirarki Pusat Pelayanan di Kota Tanjungpinang Berdasarkan Analisis Skalogram

Hasil analisis ini memberi gambaran Kecamatan Tanjungpinang Timur mempunyai potensi sebagai pusat pelayanan karena fasiltas pelayanan yang dimiliki paling lengkap diantara kecamatan yang lain. Disamping itu, hal tersebut menggambarkan adanya aksesibilitas yang tinggi di Kecamatan Tanjungpinang Timur, dimana wilayah dengan fasilitas lebih lengkap dan baik berada pada wilayah dengan aksesibilitas yang tinggi (Hardati, 2016).
Indeks Sentralitas Marshall tidak hanya melihat jumlah fungsi atau fasilitas, tetapi juga berdasarkan frekuensi keberadaan fungsi atau fasilitas pelayanan (Muliana et al., 2018). Berdasarkan frekuensi keberadaan fasilitas pelayanan pada masing-masing kecamatan (Tabel 6), bobot Indeks Sentralitas (IS) Marshall membagi kecamatan ke dalam 4 orde (Tabel 7).

Tabel 6. Jumlah Fasilitas Setiap Kecamatan di Kota Tanjungpinang

\begin{tabular}{|c|c|c|c|c|c|c|c|c|c|c|c|c|c|c|c|c|c|c|c|c|c|c|c|c|c|c|}
\hline \multirow[b]{2}{*}{ No } & \multirow[b]{2}{*}{ Kecamatan } & \multicolumn{24}{|c|}{ JUMLAH FASILITAS } & \multirow[b]{2}{*}{ JUMLAH } \\
\hline & & A & B & $C$ & D & $\mathrm{E}$ & $\mathrm{F}$ & G & $\mathrm{H}$ & 1 & J & $\mathrm{K}$ & L & $M$ & $\mathrm{~N}$ & 0 & $P$ & $\mathrm{Q}$ & $R$ & $S$ & $\mathrm{~T}$ & $U$ & $v$ & $w$ & $x$ & \\
\hline 1 & Tanjungpinang Timur & 28 & 27 & 11 & 4 & 46 & 18 & 76 & 46 & 9 & 3 & 10 & 230 & 9 & 17 & 3 & 3 & 1 & 1 & 1 & 1 & 2 & 3 & 0 & 1 & 550 \\
\hline 2 & Bukit Bestari & 15 & 21 & 9 & 7 & 35 & 16 & 42 & 33 & 4 & 3 & 2 & 189 & 4 & 7 & 3 & 3 & 9 & 0 & 0 & 1 & 3 & 5 & 0 & 0 & 411 \\
\hline 3 & Tanjungpinang Kota & 6 & 12 & 5 & 0 & 16 & 2 & 14 & 9 & 3 & 5 & 3 & 146 & 21 & 15 & 1 & 1 & 1 & 1 & 4 & 2 & 0 & 0 & 3 & 0 & 270 \\
\hline \multirow[t]{3}{*}{4} & Tanjungpinang Barat & 11 & 15 & 6 & 0 & 39 & 9 & 28 & 18 & 5 & 2 & 2 & 51 & 14 & 11 & 0 & 0 & 0 & 1 & 0 & 1 & 1 & 1 & 1 & 0 & 216 \\
\hline & TOTAL & 60 & 75 & 31 & 11 & 136 & 45 & 160 & 106 & 21 & 13 & 17 & 616 & 48 & 50 & 7 & 7 & 11 & 3 & 5 & 5 & 6 & 9 & 5 & 1 & 1447 \\
\hline & $\begin{array}{l}\text { Keterangan: } \\
\text { A. TK } \\
\text { B. SD } \\
\text { C. SMP } \\
\text { D. SMA }\end{array}$ & & \multicolumn{4}{|c|}{$\begin{array}{l}\text { E. POSYANDU } \\
\text { F. BALAI } \\
\text { KESEHATAN } \\
\text { G. MASJID } \\
\text { H. MUSHOLLA }\end{array}$} & & \multicolumn{3}{|c|}{$\begin{array}{l}\text { 1. GEREJA } \\
\text { J. WIHARA } \\
\text { K. INDUSTRI } \\
\text { BESAR } \\
\text { L. UMKM }\end{array}$} & & \multicolumn{4}{|c|}{$\begin{array}{l}\text { M. HOTEL } \\
\text { N. BANK } \\
\text { O. PASAR } \\
\text { P.UNIVERSITAS } \\
\text { Q. PUSKESMAS }\end{array}$} & & \multicolumn{4}{|c|}{$\begin{array}{l}\text { R. PELABUHAN } \\
\text { S. RUMAH } \\
\text { SAKIT } \\
\text { T. POLINDES } \\
\text { U. SMK }\end{array}$} & & & \multicolumn{3}{|c|}{$\begin{array}{l}\text { V. RUMAH } \\
\text { BERSALIN } \\
\text { W. KLENTENG } \\
\text { X. BANDARA }\end{array}$} & \\
\hline
\end{tabular}

Sumber: BPS Kota Tanjungpinang, 2019 
Tabel 7. Tingkatan Orde Marshall

\begin{tabular}{ccccccc}
\hline No & Kecamatan & $\begin{array}{c}\text { Jumlah } \\
\text { Penduduk }\end{array}$ & $\begin{array}{c}\text { Jumlah } \\
\text { Fasilitas }\end{array}$ & Bobot IS & Orde & Ket. Nilai Orde \\
\hline 1 & Tanjungpinang Timur & 83,670 & 550 & 768.88 & I & $768.88-906.05$ \\
2 & Bukit Bestari & 61,005 & 411 & 764.33 & II & $631.70-768.87$ \\
3 & Tanjungpinang Kota & 17,998 & 270 & 509.42 & III & $494.52-631.69$ \\
4 & Tanjungpinang Barat & 46,607 & 216 & 357.36 & IV & $357.34-494.51$ \\
\hline
\end{tabular}

Sumber: Hasil Penelitian, 2019

Orde I merupakan kecamatan yang memiliki jumlah fasilitas terbanyak yaitu Kecamatan Tanjungpinang Timur memiliki 550 unit fasilitas; orde II merupakan kecamatan yang memiliki jumlah fasilitas lebih sedikit daripada orde I, yaitu Kecamatan Bukit Bestari, memiliki 411 unit fasilitas; orde III merupakan wilayah yang jumlah fasilitasnya lebih sedikit dari orde I dan II yaitu Kecamatan Tanjungpinang Kota, memiliki 270 unit fasilitas; dan orde IV merupakan wilayah yang memiliki fasilitas paling sedikit dari orde I, II, dan III yaitu Kecamatan Tanjungpinang Barat memiliki 216 fasilitas. Hal ini sebagaimana penjelasan Rustiadi (2009) bahwa suatu pusat yang berorde tinggi mempunyai jumlah sarana dan jenis sarana dan prasarana pelayanan yang lebih banyak dari orde yang lebih rendah. Peta tingkatan orde tersebut dapat dilihat pada gambar 3.

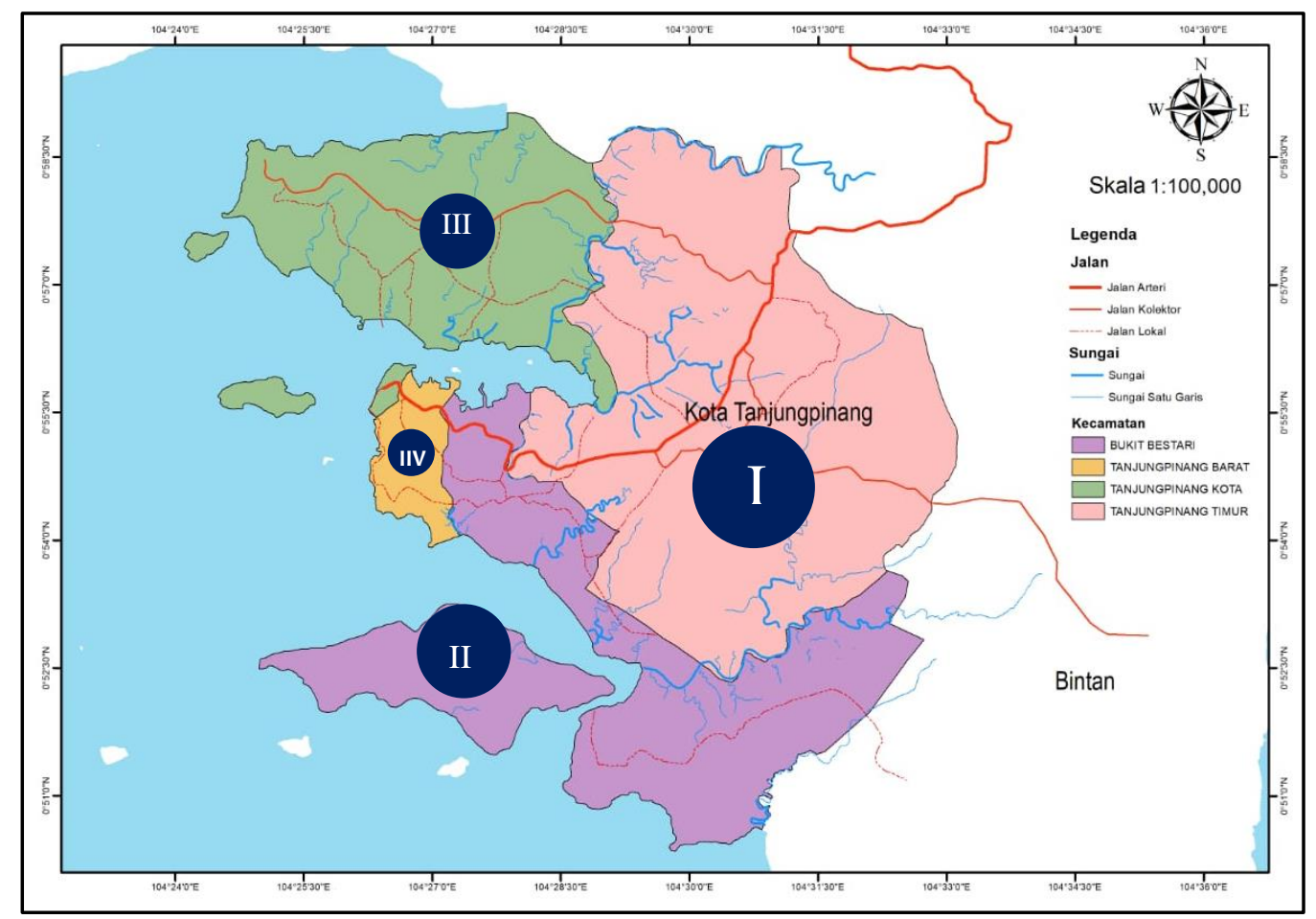

Gambar 3. Peta Hirarki Kecamatan di Kota Tanjungpinang Berdasarkan Indeks Sentralitas Marshall

Hasil analisis Indeks Sentralitas Marshail menggambarkan Kecamatan Tanjungpinang Timur masih berpotensi sebagai pusat pelayanan karena jumlah fasilitas yang dimiliki adalah terbanyak diantara kecamatan lainnya yakni 550 unit. Dengan membandingkan hasil analisis Indeks Sentralitas Marshall (Tabel 7) dengan hasil analisis skalogram (Tabel 5) menghasilkan perbedaan orde pada Kecamatan Tanjungpinang Kota dan Kecamatan Bukit Bestari. Kecamatan Tanjungpinang Kota menduduki orde III karena jumlah fasilitas yang dimilikinya lebih sedikit dari Kecamatan Bukit Bestari, namun memiliki fasilitas yang lebih 
lengkap. Sebaliknya Kecamatan Bukit Bestari menduduki orde II karena fasilitas yang dimilikinya lebih banyak dari Kecamatan Tanjungpinang Kota, namun fasilitas yang dimiliki kurang lengkap. Hal ini mengindikasikan seluruh kecamatan dalam hal ini juga dapat berpotensi berada pada orde yang lebih tinggi melalui modifikasi ketersediaan dan peningkatan jumlah fasilitas perdagangan, pendidikan, peribadatan, dan kesehatan.

\section{Analisis Interaksi Keruangan}

Dalam melihat kekuatan interaksi antar wilayah di Kota Tanjungpinang, analisis interaksi keruangan telah memberi gambaran sebagaimana yang ditampilkan pada Tabel 8 . Analisis ini menilai faktor jarak dan jumlah penduduk karena dianggap sangat erat kaitannya dengan kegiatan ekonomi dan sosial, sehingga dapat menggambarkan bagaimana daya tarik dari lokasi tersebut (Octaria \& Hidayat, 2015). Untuk mempermudah perhitungan, analisis ini menggunakan jarak darat terpendek (dalam kilometer) yang menghubungkan antara pusat kecamatan yang satu dengan yang lainnya dan selalu digunakan penduduk Kota Tanjungpinang menuju ke pusat kecamatan.

Tabel 8. Nilai Interaksi Antarkecamatan di Kota Tanjungpinang

\begin{tabular}{|c|c|c|c|c|c|c|c|c|c|}
\hline \multirow[t]{2}{*}{ No } & \multirow{2}{*}{\multicolumn{3}{|c|}{ Kecamatan }} & \multicolumn{2}{|c|}{$\begin{array}{c}\text { Jumlah } \\
\text { Penduduk (P) } \\
\text { (jiwa) }\end{array}$} & \multirow{2}{*}{$\begin{array}{c}\text { jarak } \\
\text { (d) } \\
\mathrm{km} \\
\end{array}$} & \multirow{2}{*}{$\begin{array}{c}\text { Nilai } \\
\text { Interksi } \\
\text { Antar } \\
\text { Kecamatan } \\
\text { (NA) } \\
\end{array}$} & \multirow{2}{*}{$\begin{array}{l}\text { Nilai } \\
\text { Interaksi } \\
(\mathrm{NI})\end{array}$} & \multirow{2}{*}{$\begin{array}{c}\text { Penyederhanaan } \\
\text { Perbandingan } \\
\left(\mathrm{NI} / 10^{7}\right)\end{array}$} \\
\hline & & & & Asal & Tujuan & & & & \\
\hline \multirow[t]{3}{*}{1} & Tpi. Timur & - & Tpi. Barat & 83,670 & 46,607 & 7 & $79,583,830$ & \multirow{3}{*}{$236,428,545$} & \multirow{3}{*}{24} \\
\hline & & - & Tpi. Kota & 83,670 & 17,998 & 10 & $15,058,927$ & & \\
\hline & & - & Bukit Bestari & 83,670 & 61,005 & 6 & $141,785,788$ & & \\
\hline \multirow[t]{3}{*}{2} & Tpi. Barat & - & Tpi. Kota & 46,607 & 17,998 & 17 & $2,902,536$ & \multirow{3}{*}{$110,918,966$} & \multirow{3}{*}{11} \\
\hline & & - & Bukit Bestari & 46,607 & 61,005 & 10 & $28,432,600$ & & \\
\hline & & - & Tpi. Timur & 46,607 & 83,670 & 7 & $79,583,830$ & & \\
\hline \multirow[t]{3}{*}{3} & Tpi. Kota & - & Bukit Bestari & 17,998 & 61,005 & 19 & $3,041,463$ & \multirow{3}{*}{$21,002,925$} & \multirow{3}{*}{2} \\
\hline & & - & Tpi. Timur & 17,998 & 83,670 & 10 & $15,058,927$ & & \\
\hline & & & Tpi. Barat & 17,998 & 46,607 & 17 & $2,902,536$ & & \\
\hline \multirow[t]{3}{*}{4} & Bukit Bestari & - & Tpi. Timur & 61,005 & 83,670 & 6 & $141,785,788$ & \multirow{3}{*}{$173,259,850$} & \multirow{3}{*}{17} \\
\hline & & - & Tpi. Barat & 61,005 & 46,607 & 10 & $28,432,600$ & & \\
\hline & & - & Tpi. Kota & 61,005 & 17,998 & 19 & $3,041,463$ & & \\
\hline
\end{tabular}

Tabel 8 menggambarkan Kecamatan Tanjungpinang Timur memiliki nilai interaksi keruangan paling tinggi yaitu 236,428,545, selanjutnya diikuti Kecamatan Bukit Bestari 173,259,850, Kecamatan Tanjungpinang Barat $110,918,966$ dan Kecamatan Tanjungpinang Kota 21,002,925 dengan perbandingan nilai interaksi adalah $24: 17: 11$ : 2. Perbandingan nilai interaksi ini menjelaskan nilai kekuatan interaksi setiap Kecamatan dalam bentuk sederhana sehingga dapat terlihat jelas Kecamatan Tanjungpinang Timur adalah yang paling besar diantara kecamatan yang lainnya.

Nilai Interaksi Antar Kecamatan (NA) yang paling berkontribusi pada besarnya Nilai Interaksi (NI) ke Kecamatan Tanjungpinang Timur adalah nilai interaksi antara Kecamatan
Tanjungpinang Timur dengan Kecamatan Bukit Bestari sebesar 141,785,788. Hal ini menunjukkan Kecamatan Tanjungpinang Timur dan kecamatan Bukit Bestari memiliki hubungan yang erat sebagaimana Shara (2018) menyatakan semakin tinggi nilai model gravitasi menunjukkan bahwa hubungan antar wilayah semakin erat. Kuat atau eratnya interaksi ini dipengaruhi oleh jarak antar kedua wilayah yang relatif pendek yakni sejauh $6 \mathrm{~km}$ dan memiliki jumlah penduduk antara 61,005 83,670 jiwa.

Kecamatan Tanjungpinang Kota memiliki nilai kekuatan interaksi paling kecil sebesar 21,002,925 karena dipengaruhi faktor jumlah penduduk yang sedikit dan aksesibilitas jarak yang jauh (antara 10-19 km) sehingga nilai 
kekuatan interaksi antar pusat kecamatan menjadi kecil. Jarak menjadi faktor penduduk untuk melakukan perpindahan atau pergerakan dalam memenuhi kebutuhannya.

Jika dihubungkan dengan hasil analisis skalogram, maka jelaslah Kecamatan Tanjungpinang Timur mempunyai kekuatan menarik paling besar karena fasilitas pelayanan yang disediakan wilayah ini sangat banyak dan lengkap. Perbedaan kepemilikan fasilitas pelayanan publik antar kecamatan menimbulkan pengaruh yang besar terhadap daya tarik wilayah untuk menjadi pusat pertumbuhan (Ancok \& Nurhadi, 2018). Hasil ini mendukung penelitian Gulo (2015) bahwa semakin lengkap fasilitas ekonomi dan sosial maka semakin menarik bagi penduduk untuk melakukan aktivitas di wilayah itu. Hasil analisis ini juga menggambarkan bahwa Kecamatan Tanjungpinang Timur memiliki potensi untuk berkembang, karena semakin banyak dan lengkapnya fasilitas di suatu wilayah dapat menjadi tolak ukur perkembangan wilayah (Shara, 2018). Perkembangan wilayahnya dapat dilihat dari pembangunan kawasan Perdagangan Bintan Centre yang menjadi salah satu daya tarik penduduk untuk melakukan aktivitas di wilayah itu karena lokasinya yang sangat strategis. Daerah-daerah yang lokasinya sangat strategis memiliki kemungkinan berkembangnya secara lebih cepat dibandingkan dengan daerah - daerah di sekitarnya (Sihombing \& Nurman, 2017).

Namun kuatnya interaksi yang terjadi di Kecamatan Tanjungpinang Timur memberi indikasi adanya gejala tidak meratanya distribusi pembangunan di Kota Tanjungpinang, khususnya di Kecamatan Tanjungpinang Kota yang merupakan pusat ibukota Tanjungpinang, sehingga dengan adanya pusat pelayanan ini akan memberikan kegunaan bagi pemenuhan kebutuhan manusia terhadap proses pembangunan fisik dan infrastruktur serta fasilitas-fasilitas sosial lainnya (Utoyo, 2007). Melalui analisis yang sudah dilakukan, maka dalam perencanaan ke depan Kecamatan Tanjungpinang Kota dapat mengalami modifikasi peningkatan orde melalui penambahan jumlah fasilitas dan penyediaan fasilitas yang belum ada untuk mengangkat hirarki Kecamatan Tanjungpinang Kota menjadi lebih tinggi atau sebagai pusat pelayanan utama (berorde 1). Pemerintah Kota Tanjungpinang dapat melakukan pergeseran arah pembangunan ke Kecamatan Tanjungpinang Kota untuk membangun fasilitas-fasilitas yang belum dimiliki yaitu SMK, rumah bersalin dan bandara dengan aksesibilitas yang baik.
Pembangunan SMK dan rumah bersalin akan menambah nilai jumlah jenis fasilitas Kecamatan Tanjungpinang Kota sehingga bernilai sama dengan Kecamatan Tanjungpinang Timur (memiliki 23 jenis fasilitas). Pemerintah dapat meningkatkan unitunit fasilitas perdagangan, misalnya dengan membangun pasar/kawasan perdagangan baru di Kecamatan Tanjungpinang Kota dan Kecamatan Bukit Bestari yang sebanding dengan Kawasan Perdagangan Bintan Centre sebagai potensi dan daya tarik. Peningkatan pembangunan fasilitas pelayanan ini akan mengiringi interaksi ke Kecamatan Tanjungpinang Kota, karena semakin lengkap atau semakin tinggi nilai indeks sentralitas atas fasilitas yang dimiliki maka wilayah tersebut memiliki fungsi yang lebih besar dibandingkan wilayah lain dan semakin menarik masyarakat di kecamatan lainnya untuk melakukan aktivitas di Kecamatan Tanjungpinang Kota (Gulo, 2015).

\section{KESIMPULAN}

Berdasarkan hasil analisis skalogram dan interaksi keruangan yang telah dilakukan, kecamatan yang berpotensi menjadi pusat pelayanan di Kota Tanjungpinang adalah Kecamatan Tanjungpinang Timur, karena memiliki fasilitas terbanyak dan terlengkap di antara kecamatan yang lain, yakni 23 jenis fasilitas sebanyak 550 unit. Kecamatan Tanjungpinang Timur juga memiliki potensi untuk berkembang. Hal tersebut didukung oleh nilai interaksi ke Kecamatan Tanjungpinang Timur adalah paling tinggi sebesar $236,428,545$. Hasil penelitian dapat menjadi bahan pertimbangan pemerintah Kota Tanjungpinang dalam menurunkan kesenjangan antarwilayah di Kota Tanjungpinang dengan mengoptimalkan pusat-pusat pelayanan serta melalui pergeseran arah pembangunan fasilitas pelayanan pada wilayah yang memiliki hirarki perkotaan dan nilai interaksi keruangan yang rendah.

\section{UCAPAN TERIMA KASIH}

Penulis mengucapkan terimakasih kepada Pusbindiklatren yang telah memberikan dukungan materi dan dosen pengajar Bapak Dr. Yudi Basuki, ST, MT, selaku kepala Laboratorium Geomatika Teknik Perencanaan Wilayah dan Kota Universitas Diponegoro yang telah memberi masukan dan bimbingan pada penelitian ini. 


\section{DAFTAR PUSTAKA}

Ancok, Z., \& Nurhadi. (2018). Kajian pengembangan pusat pertumbuhan wilayah di Kabupaten Klaten Zenza. Geomedia, 16(1), 13-24.

Badan Pusat Statistik. 2019. Kota Tanjungpinang Dalam Angka 2019, Kota Tanjungpinang

2019. Kecamatan Tanjungpinang Barat Dalam Angka 2019, Kota Tanjungpinang 2019. Kecamatan Tanjungpinang Timur Dalam Angka 2019, Kota Tanjungpinang 2019. Kecamatan Tanjungpinang Kota Dalam Angka 2019, Kota Tanjungpinang 2019. Kecamatan Bukit Bestari Dalam Angka 2019, Kota Tanjungpinang

Firmansyah, R., Hariyanto, \& Indrayati, A. (2016). Dinamika Sistem Kota-Kota Dan Pemilihan Alternatif Pusat Pertumbuhan Baru Di Kota Semarang. Geo Image, 5(1), 1-5. https://doi.org/10.15294/v5i2.13561

Gulo, Y. (2015). Identifikasi Pusat-Pusat Pertumbuhan Dan Wilayah Pendukungnya Dalam Pengembangan Wilayah Kabupaten Nias Identification of Growth and Hinterland Area in Developing Nias District. Widyariset, 18, 37-48.

Hailuddin, Fadliyanti, L., \& Wijimulawiani, B. S. (2018). Pusat Pertumbuhan Ekonomi Dan Kontribusinya Pada Pengembangan Daerah Pendukung Di Lombok Timur NTB. EKOBISNIS, 4(2), 35-50.

Hardati, P. (2016). Hirarki Pusat Pelayanan di Kecamatan Ungaran Barat dan Ungaran Timur Kabupaten Semarang. Jurnal Geografi, 3(1), 204-215. https://doi.org/10.1017/CBO978051171 2029

Hidayat, F. (2018). Pemerataan Harus Jadi Arus Utama Strategi Pembangunan. Retrieved from https://www.beritasatu.com/ekonomi/ 501439/

Jacob, J., \& Hasan, N. (2016). Determining The Centers of Economic Growth And Regional Development Using Scalogram Analysis (An Empirical Study In West Halmahera Regency, Indonesia). IOSR Journal of Economics and Finance, O7(04), 31-36. https://doi.org/10.9790/5933704033136

Januarman, Ahyuni, \& Purwaningsih, E. (2018). Jurnal buana. Buana, 3(3), 451-465.

Marasabessy, F. (2016). Hirarki Wilayah Kota Ternate Pasca Pengembangan Kawasan Waterfront City. Jurnal Wilayah Dan Lingkungan, $\quad 4(3), \quad 213$. https://doi.org/10.14710/jwl.4.3.213224

Muliana, R., Astuti, P., \& Fadli, A. (2018). Kajian Pusat-Pusat Pelayanan Di Kabupaten Kampar. Jurnal Saintis, 18(1), 59. https://doi.org/10.25299/saintis.2018.v ol18(1).2846

Octaria, R., \& Hidayat, P. (2015). Analisis Sektor Unggulan Di Kota Medan. Jurnal Ekonomi Dan Keuangan, 3(1), 59-71.

Rahayu, E., \& Santoso, E. B. (2014). Penentuan Pusat-pusat Pertumbuhan dalam Pengembangan Wilayah di Kabupaten Gunungkidul. Jurnal Teknik Pomits, 3(2), 290-295. Retrieved from http://www.ejurnal.its.ac.id/index.php/ teknik/article/view/7296/2088

Republika. (Online). Ketimpangan Masih Jadi Tantangan Pembangunan. Tersedia di https://nasional.republika.co.id/berita/q Ogepj430/ diakses pada 8 Desember 2019.

Rustiadi, E. (2009). Perencanaan dan Pengembangan Wilayah (2nd ed.). Jakarta: Yayasan Pustaka Obor Indonesia.

Shara, A. R. I. D. (2018). Analisis Konektivitas Wilayah di Kota Denpasar. Media Komunikasi Geografi, 19(1), 42. https://doi.org/10.23887/mkg.v19i1.13 811

Sihombing, I., \& Nurman, A. (2017). Analisis Spasial Terhadap Persebaran Fasilitas Sekunder Pariwisata Di Kota Medan. Tunas Geografi, 6(1), 25. https://doi.org/10.24114/tgeo.v6i1.834 7

Suryana, W., \& Hafil, M. (2019). Ketimpangan Masih Jadi Tantangan Pembangunan. Retrieved from https://nasional.republika.co.id/berita/q Ogepj430/

Utari, E. S. (2015). Analisis Sistem Pusat Pelayanan Permukiman Di Kota Yogyakarta Tahun 2014. Jejak, 8(1). https://doi.org/10.15294/jejak.v8i1.385 6 
Utoyo, B. (2007). Geografi Membuka cakrawala Dunia. Bandung: PT. Setia Purna.

Valetin, Z., \& Pangi. (2017). ANALISIS PENGEMBANGAN WILAYAH DENGAN PENDEKATAN SEKTORAL DAN REGIONAL DI KABUPATEN BOGOR. Seminar Nasional
Geomatika:Inovasi Penyediaan Inforasi Geospasial

Pembangunan Berkelanjutan, 185-194.

Undang-Undang Nomor 25 Tahun 2002 tentang Pembentukan Provinsi Kepulauan Riau. 